\title{
LO GÓTICO, LO FUNERAL Y LO MACABRO EN LA CULTURA ESPAÑOLA Y EUROPEA DEL SIGLO XVIII
}

\author{
Nigel GLENDINNING \\ Queen Mary and Westfield College, \\ Universidad de Londres
}

Las novelas góticas, las tragedias de mazmorra y la poesía sepulcral, en las que se reconcentra el gusto dieciochesco de lo funeral y lo macabro, se consideran con frecuencia fenómenos románticos o prerrománticos, que parecen corresponder a un cambio de sensibilidad en el siglo XVIII (Abrams, 1953). Este cambio se explica de distintas maneras: ya como manifestación puramente literaria o filosófica (engendrada en, y transmitida por, los libros; Praz, 1930), ya como consecuencia del desarrollo de la burguesía en las sociedades europeas (Hauser, 1951), ya como fruto de la introducción de nuevos cementerios y sepulcros más individualizados (Ariès, 1971 y 1974), ya como producto de cierto descenso en las creencias religiosas con su correspondiente ascenso de tendencias libertarias (Gay, 1967); o ya como resultado de las modificaciones de perspectivas y fronteras de las ciencias, que trajeron consigo una revolución psicológica en el Occidente (Foucault, 1966, segunda parte, capítulo 10). Con tales novelas, tragedias y poesías entran de lleno en la literatura del Siglo de las Luces las sombras y los presagios - despreciados por los ilustrados dieciochescos, ridiculizados por los devotos de la Razón en todas las épocas. Irrumpen con ellas también, sin duda, las corrientes socio-psicológicas constantes en la cultura, que se manifiestan asimismo en la literatura carnavalesca, reflejando las preocupaciones y los conflictos de siempre en la sociedad humana lo mismo que los impulsos instintivos. Estas corrientes podrían ser muy bien las que privilegiaban la cara oscura de la imaginación, los monstruos producidos por el sueño de la razón y las obsesiones mórbidas en la novela y la tragedia mencionadas. Son ellas muchas veces las que dan lugar preferente a los temas subversivos, sean sexuales, anti-jerárquicos, anticlericales o simplemente irracionales. La visión histórica a menudo simplifica la interpretación de los fenómenos culturales. 
Pero, en realidad, ni siquiera los estilos aceptados ni los discursos dominantes son unívocos.

La posibilidad de diversas perspectivas sobre un mismo estilo surge muy claramente en el siglo XVIII en el caso del Gótico. El desprecio de este estilo arquitectónico por los árbitros del Gusto, a principios del siglo por ejemplo, corresponde a una visión histórica desfavorable a los godos, que se consideraban progenitores de la barbarie. El gótico era primitivo para estos círculos, y sus edificios llenos de quimeras, harpías, ornamentos grotescos e irracionales, imágenes burdamente esculpidas y amontonadas sin sentido de unidad ni armonía. En la segunda mitad del siglo, en cambio, en una época en que se daba más importancia a la respuesta del espectador y al estímulo de los sentidos por la arquitectura, algunos autores vuelven a elogiar el gótico por la riqueza sensorial de sus edificios ${ }^{1}$. Tales autores se maravillan de la singular delicadeza de los monumentos góticos, alaban su ligereza o ingravidez, y hasta encuentran una elevación majestuosa en sus construcciones, que faltaba en las de la Antigüedad clásica. Gracias al cambio de enfoque, el gótico o neogótico pasaba de los jardines, en donde quedaba arrinconado, al interior de las casas. Al estilo de las grutas y los pabellones rústicos se hace el de las chimeneas, librerías y sillas de los salones. Para algunos, a pesar de todo, el gótico seguía siendo primitivo o más bien lúdico ${ }^{2}$; pero otros ya lo tomaban en serio, identificándolo con lo Sublime, tratándolo de estilo de carácter religioso, que los arquitectos podrían ofrecer a los más adictos a las tradiciones cristianas, y los estetas relacionar con el espíritu nacional de sus países ${ }^{3}$. El neogótico dieciochesco, por lo tanto, supone un abanico de actitudes y colores, lo mismo que el Neoclasicismo (Rosenblum, 1967). El signo de estilo se modifica según las diversas inclinaciones de los autores.

Valga como ejemplo de lo que este estilo podía representar el caso de Horace Walpole (1717-1797), cuarto hijo del primer ministro británico Sir Robert Walpole, que desarrolló y refinó su afición al gótico en sus viajes por Francia e Italia entre 1739 y 1741 . Empezó a remodelar la casa de su habitación en la Cuesta de las Fresas (Strawberry Hill, al oeste de Londres) en el estilo

1. Una revisión de perspectivas sobre el Gótico se encuentra en Francia en Laugier (1753, con nueva edición en 1755). Un contraste de dictámenes favorables y desfavorables aparece en Blondel (1771, I, págs. 458-459), y la continuación de su curso por Patte (1777, VI, págs. 206-207).

2. Se construían edificios góticos o neogóticos más que nada en los jardines de las casas de campo inglesas en la primera mitad del siglo XVIII (McCarthy, 1987, págs. 4-59). Primaba en estos ejemplos el valor decorativo y hasta lúdico. Aun se daban casos parecidos a principios del siglo XIX. Krafft y Ransonnette publicaron un diseño para un molino con arcos góticos (s.a., lamina 47), y elaboraron también un gabinete de lectura neogótico en 1801 (lámina 240).

3. La relación entre lo Gótico y lo Sublime se establece en el contexto de los castillos góticos en Alison (1825, I, pág. 322). Belanger trató de estimular el interés de Chateaubriand por el estilo de los monumentos góticos en 1811, subrayando el sentido religioso del mismo (Stern, 1930, pág. 290). August-Wilhelm Schlegel desarrolló su concepto fundamental del gótico como expresión de los espíritus nacionales alemán y español por la misma época (1809-1811). 
gótico de los años cincuenta, añadiéndole luego nuevas alas y accesorias ${ }^{4}$. Y en 1764 publicó anónimamente la primera novela de las llamadas góticas, El castillo de Otranto. Walpole disfrutaba con la recreación de las épocas pasadas, tenía gusto de coleccionista, y se llevó a su casa de campo detalles de las antiguas catedrales y los regios palacios (Gray, 1903, pág. 10-11). No era todo respeto en Walpole, sin embargo, para con las cosas viejas. Se divertía con ellas al cambiarlas de contexto, casi parodiándolas. En la novela hay una labor de anticuario parecida; motivos de risa también; y un espíritu de rebeldía edípica, sobre todo en el desparpajo del joven Teodoro y sus conflictos con el tiránico príncipe de Otranto, Manfredo, padre y esposo cruel y egoísta entrado en años.

La imaginación asimismo desempeña un papel importante en la arquitectura y la novela walpolianas. La refuerzan los recuerdos de otros edificios en su casa, ya que la facultad imaginativa servía para "rememoriar las imágenes" en el siglo XVIII (Diderot, 1959, pág. 218). El estímulo de la fantasía vuelve a primar y es más original en El castillo de Otranto. El mismo autor subraya su importancia en uno de sus prólogos, lamentando que se hubiesen tapado "las grandes fuentes imaginativas" en la novela moderna, para poder reflejar mejer la vida de todos los días y los móviles de la conducta humana (Walpole, 1907 , pág. LVI). Pero el uso que Walpole hace de la imaginación en El castillo de Otranto es muy distinto del de los proyectos arquitectónicos mencionados. En su casa, la fantasía se relaciona con objetivos exaltados — con lo noble y lo espiritual- mientras que en la novela se asocia con la ambición, la codicia y el abuso del poder de un tirano. La novela ofrece una imagen negativa, al parecer, de los valores celebrados en su casa, aun cuando los aparecidos sean heroicos y virtuosos. En la casa, tan sólo la presencia de retratos de personajes de la corte de Enrique VIII, o de una chimenea de dormitorio inspirada en el altar mayor de la catedral de Ruán (Gray, 1903, III, págs. 10-11), producen un desfase contextual con posibilidades cómicas o burlescas, que hace sospechar cierta ambigüedad o ironía. No cabe duda, desde luego, que la existencia de humor y juego en estas obras aumenta su potencial subversivo y disidente.

En El castillo de Otranto se exige una visión irónica por parte del lector, puesto que se trata de una novela llena de contrastes e incoherencias. En cierto sentido la trama es consoladora, ya que el tirano Manfredo, nieto de un usurpador y celoso él mismo de su poder, malogra la sucesión al trono que ambiciona para su familia, y el principado vuelve a los descendientes del último soberano legítimo. Los malos caen en la novela, por otra parte, y algunos de los buenos suben. El joven Teodoro, por ejemplo, de origen incierto

4. Walpole alquiló la casa en 1747 , y se compró la finca al año siguiente, adquiriendo más terreno en lo sucesivo. Afirmó que tenía la intención de construir "un pequeño castillo gótico" en 1750, y empezó a edificarlo en 1753-1754. De aquellos años son el refectorio y la biblioteca. Se hizo nuevo dormitorio en 1759 y una galería para cuadros, claustro y torre en 1760-1761. Construyó una capilla en 1772-1773 (McCarthy, 1987). 
y al parecer modesto, cuya vida peligra constantemente en la obra, se revela al final tronco de la línea de príncipes legítimos y se casa con una hermosa princesa. Todo esto es, desde luego, consolador y un poco parecido a las tradiciones de los cuentos folklóricos, con sus historias de jóvenes que necesitan luchar mucho para hacerse lugar en el mundo, ayudados a veces por genios protectores.

Es cierto que la providencia protege, en cierto modo, en El castillo de Otranto también. Pero la ineficacia de los buenos es lastimosa. Los más de ellos son mujeres, que no saben hacerse valer contra el poder del tirano, ni quieren poner en tela de juicio su autoridad. Para que sobrevivan algunos buenos es imprescindible la intervención de fuerzas sobrenaturales, en una serie de portentos, sueños y visiones. Sin embargo, éstos tampoco convencen mucho al lector. Los portentos - yelmos encantados, sables gigantescos, casos de agnición o anagnórisis- o son cómicos en sí, o parecen ridículos por su manera de darse a conocer, con frecuencia a través de los balbuceos interminables de la miedosa servidumbre. El terror, por lo tanto, que debería de realzar el papel del Cielo, resulta risible a menudo en vez de sublime ${ }^{5}$. Lo inverosímil de estos sucesos y el consiguiente "suspense" estimulan la imaginación, pero de un modo tan exagerado que provocan más bien la risa que la admiración. Como consecuencia, se socava la autoridad providencial desde el punto de vista del lector.

En las novelas góticas posteriores en Inglaterra, los recursos cómicos (cuando los hay) no afectan tanto a la Providencia. Se disminuye la cantidad de elementos sobrenaturales, y algunos de los autores - Mrs. Radcliffe, por ejemplo- procuran dar siempre una explicación racional de los sucesos que parece sobrenaturales en el primer momento. Varía mucho, por otra parte, la fuerza subversiva y anti-autoritaria en estas novelas. Matthew Lewis, autor de El monje (1795) y de un drama titulado El espectro del castillo (1798) con elementos "góticos", y Mrs. Radcliffe, son bastante audaces. Hay en sus novelas abusos del poder en las diversas jerarquías, en el clero y la nobleza, sobre todo, y crítica implícita o explícita de ellos. Clara Reeve, en cambio, es más conservadora. Hay más figuras-padre buenos en El viejo barón inglés, y ningún humor disidente. Otro elemento positivo, que no se encuentra en El castillo de Otranto, es la naturaleza, cuya belleza y sublimidad, aun cuando realcen los efectos terroríficos de los castillos aislados, manifiestan la fuerza y la bondad divinas en contraste con la maldad humana. Los aspectos sublimes del paisaje montañoso entran en juego poderosamente en las novelas de Mrs. Radcliffe, y

5. Los contemporáneos de Walpole y alguna de sus imitadoras - Clara Reeve- hacen constar el carácter risible de algunos de los episodios "terroríficos" de la novela. Clara Reeve se refiere a esto en el prefacio de la segunda edición de su novela The Old English Baron. A Gothic Story (1967, págs. 4-5). El poeta Thomas Gray no dejó de aprovechar las posibilidades cómicas del estilo gótico en la arquitectura, y hay rasgos paródicos en su descripción de un palacio gótico en el poema A Long Story. 
contribuyen también al impacto del Frankenstein (1818) de Mary Shelley. Esta última novela parece cercana a sus antecedentes góticos con respecto al ambiente oscuro, el terror y la fuerza del mal, aunque distante de ellos en cuanto al uso de la imaginación. Ésta se inspira en los avances científicos y las invenciones de su tiempo en Frankenstein: nuevas fuentes del mal en manos ambiciosas y obsesivas, en un mundo apto a juzgar por las apariencias.

El impacto de estas novelas inglesas en otros países es bastante inmediato. En Francia se las puede relacionar también con algunos elementos del llamado "género sombrío", y sobre todo con el teatro de Baculard d'Arnaud en los años setenta y ochenta, y las obras de Loaisel de Tréogate por la misma época (Estève, 1923). En estos escritos y dramas hay castillos de la era feudal, selvas aisladas y capillas arruinadas; pasillos y bóvedas subterráneas; todo el aparato de mazmorras y calabozos antiguos que se encuentran también en la novela gótica. Hay también en este tipo de obra historias de enamorados recluidos en conventos o monasterios.

Los móviles que se aprecian en estos autores son parecidos a los de los novelistas góticos. Baculard d'Arnaud, por ejemplo, en el prólogo de sus Epreuves du sentiment, realza el mérito del estudio de épocas pasadas, después de hablar de la importancia del sentimiento, insuficientemente desarrollado a su ver por la enseñanza moderna, obsesionada por la primacía de la razón (1779, I, págs. III y sigs.). Muchos modernos tan sólo raciocinan acerca de la antigüedad; no la sienten. En Dolbreuse, Loaisel de Tréogate afirma que el hombre del siglo vuelve hacia la verdad bajo la influencia del sentimiento, no de la razón ${ }^{6}$. Todo lo que puede reforzar la intensidad del afecto se aprecia, y Baculard d'Arnaud se refiere, en el prólogo del Conde de Comminge, a la utilidad de la sombra cuando se trata de estimular los sentimientos del público. Alude a la práctica de pintores como Rembrandt, Rubens y Poussin, que llenaban sus cuadros de tonos oscuros para realzar los efectos sublimes. Entre los poetas hay una tonalidad semejante (con resultados parecidos) en el Infierno del Dante, en el Paraíso perdido de Milton y en las Noches de Young (D'Arnaud, 1768, págs. VII y sigs.).

La historia del conde de Comminge inspiró a dos autores a fines del siglo XVIII, y tiene una relación evidente con el género de novelas y dramas que nos interesa ${ }^{7}$. Es una historia de amores desgraciados, consecuencia de la enemistad

6. Así lo declara el título de esta novela: Dolbreuse ou l' homme du siècle, ramené à la vérité par le sentiment \& par la Raison (1785).

7. El drama de Baculard d'Arnaud fue inspirado por una novela de Mme de Tencin (Le Comte de Comminge, 1735). Hay una epístola poética sobre la misma historia en la Collection d'Héroïdes et pièces fugitives de Dorat, Colardeaux, Pezay, Blin de Saint-More \& autres (1769, I, págs. 25 y sigs.). En esta última edición se incluye también un extracto de las Memorias del conde de Comminges, sin duda, las de la ya mencionada Mme de Tencin. Se publicó una versión española del poema de Dorat, traducida por D.M.A. de C. (1803). 
de dos familias y el rigor de los padres. Los jóvenes - Comminge y su amiga Adelaida - han sido criados juntos y se quieren. Pero los padres de Adelaida la casan con otro, y el conde, por su parte, debe contraer matrimonio con una hija de la Casa de Foix. Se le encierra en una torre cuando quiere renunciar a este destino, pero visita nuevamente a su antigua amiga al salir de la prisión. Desgraciadamente, el marido de esta última encuentra a los amigos juntos y hiere al conde con su espada. Comminge hiere al otro y después se mete monje, condolido de sus acciones. Muerto el marido a consecuencia de la herida, Adelaida entra disfrazada en el mismo monasterio que su amigo. Allí se descubren los amantes justo antes de morir, y caen en el mismo hoyo.

Los amores frustrados se celebran en esta obra, y las sombras, las bóvedas y demás aspectos lúgubres subrayan la negrura y tristeza de la vida. La incomprensión de los padres en el drama recuerda las novelas góticas, en las que los conflictos familiares y los abusos de la patria potestad son frecuentes. En este caso, como en otros, los jóvenes son víctimas de las ambiciones y rencillas familiares, aunque también de la adversa fortuna. Por esto no se trata de una tragedia de tipo aristotélico, en la cual el error o la culpabilidad del protagonista produce la crisis.

El conde de Comminge no llegó a estrenarse hasta el año de 1790, después de la Revolución Francesa, quizás precisamente por la visión negativa de la autoridad paterna que implica. La crítica de un padre por entonces podría tener un sentido alegórico, relacionado con el poder de las altas jerarquías y la monarquía misma. En una versión poética anterior a la misma leyenda -la de Dorat en una de sus Héroïdes - se zanja la crítica al respecto (1769, I, págs. 25 y sigs.). El conde empieza a hablar mal de su padre al final, pero en seguida se corrige, pidiendo perdón. No disminuyen, por esto, los efectos melancólicos y pesimistas en el poema de Dorat. Incluso la presencia de láminas en las ediciones de Dorat, como en las de Baculard d'Arnaud también, subraya la tenebrosidad de la historia. Las escenas representadas son nocturnas u oscuras: un sótano con una cruz y calaveras; una monja (Adelaida) a punto de expirar; el conde al lado del hoyo que prepara para su propio entierro. Otras obras de la época postrevolucionaria, en cambio, buscan desenlaces más esperanzadores. En éstas los amantes se salvan; cásanse y viven felices.

En la novela y el teatro se proyectan o dramatizan los sentimientos y preocupaciones de la sociedad y del autor en el terreno de lo funeral, lo lúgubre o lo macabro. En la poesía también existen formas indirectas dialogadas, por ejemplo, como las églogas, o de ficticio narrador como las cartas al estilo de las Heroidas ovidianas, en las que se pueden tratar los mismos temas o expresar emociones parecidas. Hay otras formas, en cambio, donde la voz del poeta parece sonar más personalmente, aun cuando se trate de temas filosóficos o se escriban poemas más bien meditando sobre la muerte que expresando sentimientos o experiencias íntimos. 
Un caso muy especial de la poesía sepulcral en el siglo XVIII es el de poeta inglés Edward Young, pastor protestante y autor de un poema en nueve partes o "noches", titulado El lamento, o pensamientos nocturnos (The Complaint, or Night Thoughts). En este conjunto poético, el escritor parte de experiencias propias, pero procura despersonalizarlas para llegar a conclusiones generales acerca del lugar del dolor en la vida humana, con ejemplos del impacto de la muerte de una persona querida sobre los afligidos. También introduce personajes ficticios en diversas secciones de la obra, con experiencias "propias", con el mismo fin de universalizar las observaciones y sensaciones recogidas. Hubo versión francesa en prosa de este largo poema, saneada desde el punto de vista de la doctrina, que llevó la obra a países católicos (Le Tourneur, 1769). Una traducción española, incompleta, salió en la colección de Obras de Eduardo Young... traducidas por Don Juan de Escoiquiz, publicada en Madrid entre 1789 y 1797. El ambiente nocturno, la riqueza de las imágenes y la forma epigramática en que se expresaban los pensamientos filosóficos gustaron. Pero lo que aseguró el éxito de las Noches de Young no fue tanto el doloroso sentir de los personajes, ni las ideas, como el valor que los lectores dieciochescos daban al elemento autobiográfico, fácil de deducir de la Vida de Young, que se incluía en muchas ediciones del poema. Los lectores siempre tienen en cuenta las experiencias del autor, cuando se trata de los temas del amor y de la muerte en la literatura. Pero se acrecienta la respuesta del lectorado a lo personal en el siglo XVIII, al parecer. Otro aspecto seductor del poema de Young sería la conclusión de la última Noche, donde las estrellas reflejan la grandeza de Dios y la bondad del universo creado por Él. Con esto se tranquiliza la inquietud de los afligidos, después de los momentos de tormento y desesperación experimentados por ellos a raíz de sus desgracias. Este fin feliz, algo distinto del de los desenlaces de novela normales, sirvió también para borrar la impresión de reacciones pesimistas ante la vida, evocadas de vez en cuando en la obra.

$\mathrm{El}$ auge de las emociones en relación con lo funeral, lo lúgubre y lo gótico no se puede rastrear tan fácilmente en el arte. Es cierto que las Carceri de Piranesi corresponden al mismo gusto que la novela gótica en algunos aspectos ${ }^{8}$, y la representación de la muerte de un padre de familia o de un general en campaña es bastante frecuente en la pintura de la época. Surgen los aparecidos asimismo en los grabados de la serie shakesperiana publicada en Londres por Boydell $1^{9}$. Pero

8. La única conexión, en realidad, es el tema de la cárcel. Los encarcelados de Piranesi no se encuentran solos, ni están encerrados en calabozos subterráneos, como era el caso en muchas novelas. Sin embargo, la angustia de los recluidos se percibe en los grabados lo mismo que en las novelas góticas.

9. Aparecen las sombras de cuatro reyes en la primera escena del Acto VI de Macbeth, representadas en un cuadro de Sir Joshua Reynolds (grabado por Thew), y vuelan.brujas por el aire en una pintura de Fuseli, acompañadas por una extraña cara que expresa el horror, en una ilustración para la tercera escena del Acto primero de la misma tragedia (grabada por Caldwell) (Santanietlo, 1968, XXXVII y XXXIX). 
en el arte resulta más difícil separar los sentimientos personales de la retórica. Las figuras mal vestidas, perdidas por las extensas galerías o escaleras de las vastas cárceles de Piranesi, ¿reflejan las emociones del mismo grabador, o son personajes teatrales, por así decirlo, que representan la miseria o el terror de los encarcelados ante la perspectiva de los rigores de la justicia? Los padres que se mueren rodeados por sus familias en los cuadros del siglo XVIII suelen ser ficticios, ejemplares o moralizadores. Los generales pintados en el trance de morir, entre edecanes, oficiales y soldados, en cambio, son reales las más de las veces y no ideales. Pero aquellas muertes, ¿sirven para desencadenar el llanto y el dolor del espectador y son catárticos para el artista, o son tan sólo ejemplo del valor militar, del sacrificio hecho para la patria, y de la ecuanimidad del héroe frente a su fallecimiento ${ }^{10}$

Volviendo al tema del estilo gótico en la arquitectura, y pasando ya a España, es evidente que tampoco se apreciaba mucho a principios del siglo XVIII. Se dan fórmulas para la construcción de los arcos apuntados en libros como el de Tomás Vicente Tosca (Tratados de arquitectura civil, montea y cantería y relojes), pero está bastante claro que el estilo gótico no se aprobaba. Dice Tosca que los arcos apuntados y elípticos son "propios del orden gótico", pero "a más de no ser hermosos, son algo débiles" (1794, pág. 105). El orden gótico es difícil de ejecutar bien, y aun cuando se logre "después de bien ejecutado y trabajado, no es hermoso" (1794, pág. 60). En la segunda mitad del siglo, en cambio, hubo españoles menos reacios con respecto al gótico. Ponz, por ejemplo, en las descripciones de edificios importantes en su Viaje, demuestra cierta simpatía por los monumentos góticos. Pasa lo mismo con otro viajero y académico de San Fernando, el marqués de Ureña, cuyo Viaje por Europa, hecho en 1787 y 1788, acaba de publicarse por primera vez (1992). La delicadeza o finura es lo que Ureña más destaca en este estilo. Una de las capillas de la abadía de Westminster le parece "en lo gótico de lo más delicadamente ejecutado que he visto hasta ahora" (1992, pág. 314). En Amiens, el cuerpo de la iglesia mayor es "delicado en su género" (pág. 269), y la catedral de Amberes, "así por su altura y bella forma en lo gótico, como por su diafanidad y delicadeza" le parece probablemente sin igual en Europa (pág. 532). Mas, en su Viaje, Ureña sólo parece disfrutar de estos edificios parcialmente y nunca del todo. Es como si no hubiese más posibilidad de unidad que la clásica.

10. Se representó la muerte del general Wolfe en un cuadro famoso de West (1770), y la de un héroe anónimo en una pintura de James Barry (1776). Se grabó el cuadro de West, como también el de la muerte del Mayor Pierson, por Copley, para una de las series de Boydell (Friedman, 1976, págs. 39 y 49). En Francia, David pintó La muerte de Séneca (1773), la escena en que se devuelven a Bruto los cadáveres de sus hijos (1789) y el asesinato de Marat (1793). Es de notar el carácter no heroico del cuerpo de Marat, que hace contraste con otras representaciones de la muerte de personajes históricos. 
$\mathrm{Y}$, sin embargo, en otro escrito suyo - las Reflexiones sobre la arquitectura, ornato y música del templo, publicadas en Madrid en 1785- el mejor estilo gótico le parece digno de imitarse. "Podrían los Artistas Filósofos tomar sabias lecciones de la arquitectura gótica del mejor tiempo", afirma Ureña (pp. 150 y 215-216). Se tendrían que reprobar "muchas ideas mezquinas y no pocas deformidades", pero en medio del detallismo característico del estilo hallarían "rasgos de simplicidad, de verdad, de propiedad, de unidad, de carácter, de armonía y de euritmia" (pp. 150 y 216). Estas ideas favorables al gótico no son únicas, pero sí algo raras. Lo normal en España seguía siendo el deseo de corregir y modificar los monumentos góticos: poniéndole nueva fachada neoclásica a la catedral de Pamplona (Ventura Rodríguez, 1783); e introduciendo capillas neoclásicas en la de Valencia. Tan bien hizo Andrés Gilabert su labor en este último caso, que ha sido difícil sacar las capillas y dejar el conjunto en su estado primitivo, no hace muchos años.

Con respecto al neogótico en la arquitectura española de fines del siglo XVIII y principios del XIX, escasean los ejemplos conocidos. Se creó un "gabinete gótico" en el Palacio de la Moncloa en Madrid, a la hora de renovar la antigua Huerta de Eliche en los años ochenta, tarea emprendida por la duquesa de Arcos, asesorada por su hermano Don Pedro de Silva, entre 1781 y 1784, y continuada después por la famosa Cayetana, duquesa de Alba, a partir de entonces (Ezquerra del Bayo, 1929; Glendinning, 1992, pág. 47). En aquel caso se trataba de un oratorio pequeño, nada más. Dominaban la decoración de la casa los adornos clásicos, las ninfas ligeramente vestidas del estilo pompeyano, y los trompe-l'oeil paisajísticos. Hubo por la misma época conato de hacer una sala neogótica en la Casita del Pardo, junta con otras igualmente exóticas, estilo turco, egipcio y chino en el mismo edificio y la Casita de El Escorial (Sancho, 1989a, pp. 17-31; 1989b, pp. 31-36). Pero no se aprobó el proyecto gótico - obra de Dugourc, inspirada en parte en los arcos de la catedral de Ruán, aunque híbrida entre gótico y clásico a decir la verdad- y no sabemos de otros intentos hasta 1830, cuando surge de nuevo el neogótico en una de las construcciones edificadas para celebrar el nacimiento de la futura Isabel II.

Existen, en cambio, elementos góticos en la literatura española por aquella época. Las portadas de los libros ofrecen bastantes ejemplos de letra más o menos gótica en España en las primeras tres décadas del siglo XIX ${ }^{11}$. Hay rasgos de la novela gótica en algún episodio de La Leandra de Antonio Valladares de

11. Hay letra gótica (derivada casi seguramente de libros alemanes) en la portada de las Reflexiones sobre la naturaleza, o consideraciones de las obras de Dios en el orden natural de Sturm, traducidas al francés y de éste al español (Madrid, Benito García, 1803); y en dos ediciones de la Constitución de Cádiz (1820 y 1822). La portada de la edición de las Noches lúgubres de Cadalso, hecha en Valencia por Cabrerizo (1817), tiene también algún rasgo gótico. Existirán, sin duda, muchos ejemplos más. 
Sotomayor (1797-1807), y lo mismo ocurre con El Valdemaro de Vicente Martínez Colomer (1792) (Alvarez Barrientos, 1991, pág. 278; Carnero, 1985, págs. 39 40). Hay fantasmas agresivos y terroríficos hasta en el sueño del Filósofo en la Carta X de El evangelio en triunfo de Pablo de Olavide (1797). Las traducciones de novelas góticas extranjeras, sin embargo, tardan en llegar a España. Sólo en los años veinte del siglo XIX se publican versiones españolas de dos novelas de Ana Radcliffe: El confesionario de los penitentes negros (o sea, El italiano), editado en Madrid en 1821; y La abadía de la selva, que se dio a la estampa primero en español en París en 1825, para salir después en Madrid en 1830. No sorprende que la crítica de la Inquisición y la perversa psicología de un monje en El confesionario hayan tenido que esperar una época liberal para publicarse.

En el teatro español del mismo período aparecen también obras inspiradas en la literatura del terror y de la sombra, y en algún sentido góticas por lo tanto. Una carta escrita a Don Dionisio Solís por Leandro Fernández de Moratín describe el fenómeno en Septiembre en 1815, veinte años después de la aparición de Los experimentos de sensibilidad de Baculard d'Arnaud, en versión española. Escribe Moratín desde Barcelona, y dice lo siguiente: "En este emporio cataláunico asoman la cabeza, bastante a menudo, tres o cuatro poetas ropavejeros, muy amigos de sepulcros, paletillas, cráneos rotos y tierra húmeda, con cadenita, jarra de agua, media morena (frase que significa "hogaza", según Cueto), y pobre mujer embovedada, que llora y gime, hasta que en el quinto acto bajan con hachas y estrépito, y el crudo marido la abraza tiernamente, y la consuela, diciéndola que todo aquello no ha sido más que una equivocación. El auditorio queda contento, los empresarios ni más ni menos, los autores dicho se está, y como, por fortuna, las tales piezas no atraviesan ni el Llobregat ni el Bessós, a nadie hacen daño. Mañana echan una, nuevecita, de cinco ahorcados..." (Cueto, 1869, pág. ccxxv, nota 2). El comentario de Moratín refleja bien a las claras la oposición de los ilustrados españoles a la falta de verosimilitud, de racionalismo y de utilidad en los dramas referidos. Pero la frecuencia de las representaciones de este tipo de obra, que consta de la carta de Moratín, no deja de probar su popularidad, y señala el gusto que había por lo irracional y lo inverosímil en el gran público.

No sé a qué piezas se refiere el comediógrafo español en esta carta. Pero hay por lo menos una tragedia anterior, de autor célebre, que sigue la línea gótica a todas sombras: El duque de Viseo de Quintana. Este drama está basado, como se sabe, en El espectro del castillo de Matthew Lewis ya mencionado; y fue acogido con una reseña harto severa, de tipo moratiniano, al estrenarse en 1801 (Dérozier, 1968, I, págs. 76 y sigs.). Para el crítico desdeñoso y remilgado, se trataba de "uno de los monstruosos dramas, forjados sólo para horrorizar a los espectadores", con "un tejido de atrocidades, un cuento inverosímil, cargado de incidentes inconexos y de situaciones forzadas". Quintana era consciente de 
los problemas que la obra de Lewis podía tener, al trasladarse de las tablas londinenses a los teatros menos libres de Madrid (Quintana, 1852, pág. 41), y había modificado bastante el original, evitando las exageraciones más extremadas, simplificando la trama, y sustituyendo a la aparecida por sueños y pesadillas. Desaparece en su versión, por completo, la sombra vestida de ropa blanca y rociada de sangre. Pero Quintana creía que los efectos tremendistas de la tradición gótica eran compatibles con la difusión de ideas serias. Por esto, sin duda, introdujo en su adaptación el tema del trato de los esclavos negros, interesante lo mismo para los ilustrados como para el gran público. No omitió el rasgo popular de la crítica de los magnates perversos o injustos, aunque pasó por alto algún ejemplo de "suspense" democrático, por el que la señorita principal parece huérfana y de orígenes modestos al comienzo, cuando el joven aristócrata (disfrazado) se enamora de ella.

Quintana, que no se permitió espectros en el teatro, los admite desde luego en sus poemas. Si bien don Juan de Padilla no es más que la encarnación de una figura histórica, evocada para fines políticos, los personajes que dialogan en $E l$ Panteón del Escorial salen, en efecto, de sus sepulcros, ofreciendo "mil terribles imágenes" a la fantasía del poeta (Quintana, 1813, pág. 233). En la época de la Guerra de la Independencia, Quintana y otros poetas, como Arriaza y Beña, invocaban a los espíritus de los héroes españoles medievales para animar a sus contemporáneos en la lucha contra los invasores franceses ${ }^{12}$. Los autores de poemas de este tipo se aprovechan de la mezcla de terror y admiración - temor reverencial- que suscitan las sombras para estimular la sensibilidad y las emociones de sus lectores. Goya sigue la misma pauta en su Coloso (Glendinning, 1963, págs. 363-366), y vuelven los aparecidos en su arte en las dos figuras que vuelan en el cuadro llamado Asmodeo, entre las Pinturas Negras, y, en forma más misteriosa, en uno de los Disparates. Huelga decir que Goya corrió toda la gama de los sentimientos provocados por la muerte-desde la desesperación y el horror hasta la piedad, el elogio del sacrificio y la satisfacción que se experimenta ante la caída de un enemigo- en Los desastres de la guerra. En esta última obra añade a las representaciones de los muertos en la lucha y los fallecidos por hambre, las tremendas escenas de fusilados y cadáveres mutilados.

Al hacer un dibujo o diseño para la tumba de la la duquesa de Alba, Goya sigue un estilo totalmente diferente: convencional y clásico - una especie de Deposición o Pietà, con un grupo de figuras que forman pirámide (GassierWilson, no. 759; Ezquerra del Bayo, 1959, pp. 256 y 257). La imagen es controlada y consoladora, como tenía que ser, sin duda, tratándose de un diseño

12. En el poema de Quintana A España después de la revolución de Marzo, escrito en Abril de 1808, aparecen las sombras de Fernando III, Gonzalo de Córdoba y Mio Cid; Arriaza en su Profecía del Pirineo, escrita también en 1808 , introduce un coloso o titán medio desnudo, que representa a España, figura alegórica más que espectro. Se introduce la sombra del rey Jaime I en un poema del mismo tipo y época, por Cristóbal de Beña, lanzando el reto de España contra Francia. 
para el sepulcro de la duquesa en una cripta. Algo parecido se encuentra muchas veces en las elegías de la época, que procuran estetizar la muerte del ser querido, sacándole el aguijón a la muerte misma. La desesperación, la violencia, incluso la ira, que la muerte de un amigo hace estallar a veces, se callan en la elegía clásica, exponiéndose tan sólo el dolor agudo, el elogio del fallecido, el estoicismo frente a la muerte, que formalizan el sentido de pérdida. Pero hay excepciones, y una de ellas en la época que nos interesa es precisamente un poema de Quintana, En la muerte de un amigo. Esta elegía empieza de una manera convencional con ideas de soledad y presagios de muerte sentidos hace tiempo. Mas Quintana cambia de dirección casi en seguida, dando una imagen del muerto sobradamente real, e incapaz de escuchar al poeta. El amigo no está en los campos elíseos, ni en el cielo, sino "en ese seno misterioso, donde / lejos del mundo el infelice vaga" (Quintana, 1813, pág. 189).

Se consuela el poeta momentáneamente, pensando que otros oirán sus expresiones de dolor y el elogio de su amigo, pero pronto manifiesta de nuevo su pesimismo, ante la falta de gente virtuosa capaz de comprenderle, y el exceso de perversos en el mundo. Con tal perspectiva prefiere morir, y da por terminado el poema.

Esta elegía de Quintana acaba rechazando casi todas las posturas convencionales de este tipo de poema, y hace un contraste muy fuerte con las escritas por Jovellanos, Meléndez Valdés y Arriaza, que procuran llegar a conclusiones positivas, consolados por las cualidades del fenecido, por la inevitabilidad de la muerte, por la simpatía de los amigos o de la naturaleza misma ${ }^{13}$. Incluso Cienfuegos, que coincide con Quintana en algunos rasgos de su poema $A$ un amigo en la muerte de un hermano, termina pensando en el futuro y en la consolación de la amistad. Se podría decir quizás que, en el poema de Quintana, tan sólo la forma misma, el vocabulario, el ritmo y la rima o asonancia (presentes de vez en cuanto) imponen orden o control -algo positivosobre los sentimientos desgarradores del autor. No quería Quintana perder el control del todo, desde luego, y no le gustaba tampoco que otros autores lo perdieran. Hizo una crítica muy violenta, por ejemplo, de las Noches lúgubres de Cadalso, y despreciaba los excesos de terror en los dramas de Baculard d'Arnaud y sus imitadores (Glendinning, 1993, pág. 15; Quintana, 1852, pág. 82). No le gustaba, sin duda, la confusa mezcla de razón e irracionalidad, de

13. Basamos estas conclusiones en el análisis de las elegías siguientes: Jovellanos, Oda sáfica al capitân don José de Álava - En la muerte de Doña Engracia Olavide; Meléndez Valdés, Oda en la muerte de Filis, Oda a la mañana: en mi desamparo y orfandad, Oda a la muerte de Nise, Elegía. En la muerte de Filis, seguida del Epitafio del sepulcro de Filis y un Soneto renunciando a la poesía después de la muerte de Filis, Oda al Dr. D. Antonio Tavira ... en la muerte de su hermana, Elegía. La Virtud. En la temprana y dolorosa muerte de un hombre de bien; Arriaza, La Compasión. Canto fúnebre a la muerte del excelentísimo señor duque de Alba; Cienfuegos, A un amigo en la muerte de un hermano y La Escuela del Sepulcro. A la señora marquesa de Fuentehijar con motivo de la muerte de su amiga la señora marquesa de las Mercedes; Quintana, En la muerte de un amigo. 
desesperación y fe en sus propias virtudes, de ideas subversivas sobre la vida y la sociedad en la obra de Cadalso. Y, sin embargo, siente la necesidad de expresarse con pasión y hasta con violencia ante la muerte de un amigo. Es precisamente por esto que tales autores conservan su personalidad en sus obras, y no se esconden completamente debajo de los convencionalismos de su tiempo.

En todos estos escritos hay mucho de lúgubre, pero casi nada macabro. Porque lo macabro está en la mente del espectador o del lector en el siglo XVIII español, más que en la del autor. Quizás valga el epíteto para la obsesión con los gusanos y la podredumbre de Tediato, en las Noches lúgubres de Cadalso, harto más evidente en la Cuarta Noche (no auténtica) que se incluyó en la edición de las Noches publicada en Madrid en 1822. Quizás valga también para los cadáveres que vuelan en el Asmodeo de Goya, si es que son, en efecto, cadáveres. Lo cierto es que la palabra "macabro" falta en los diccionarios españoles del siglo XVIII, aunque esto no quiere decir que la idea de lo macabro estuviera ausente en aquella época, ni en otras anteriores tampoco. El concepto se podría aplicar, desde luego, a las imágenes en torno a la muerte recogidas por la religiosidad popular entonces. ¿No se podría aplicar asimismo a los cuadros de las Postrimerías, pintados por Valdés Leal en el siglo XVII, para la Caridad de Sevilla? Lo macabro entra y sale, en compañía de la muerte, en casi todas las épocas. Lo funeral, en cambio, tiene que respetar las diferentes costumbres y modas de distintos momentos históricos. En el siglo XVIII pasa por los castillos de las novelas góticas, las mazmorras de las tragedias y los sepulcros poéticos, como por su casa. En el arte posa lo macabro en las escenas de brujerías de los Caprichos y, en Inglaterra, en los dibujos de Fuseli.

\section{BIBLIOGRAFÍA}

ABRAMS, Meyer Howard. 1953. The Mirror and the Lamp. Romantic Theory and the Critical Tradition, Oxford, OUP.

ALISON, Archibald. [1790] 1825. Essays on the Nature and Principles of Taste, Edimburgo, Herederos de D. Willison.

ÁlVAREZ BARRIENTOS, Joaquín. 1991. La novela del siglo XVIII (Historia de la literatura española, ed.R. de la Fuente, tomo 28), Madrid, Ediciones Júcar.

ARIÈS, Philippe. 1971. Histoire des populations françaises, París, Editions du Seuil.

- 1974. Western attitudes towards Death, Baltimore, Johns Hopkins.

BACULARD D'ARNAUD, François T. [1764] 1768. Le comte de Comminge, ou Les Amans malheureux, París, Le Jay.

BLONDEL, Jacques François. 1771-1777. Cours d'architecture, ou Traité de la décoration, distribution \& construction des bâtimens; contenant les leçons données en 1750 \& les années suivantes, París, Desaint-Viuda de Desaint. 
BOYDEL, John y BOYDELL, Josiah. Véanse FRIEDMAN, Winifred y SANTIELLO, A.

CADALSO, José. 1993. Noches lúgubres, ed. Nigel GLENDINNING, Madrid, Espàsa-Calpe.

CARNERO, Guillermo, ed. 1985. Véase COLOMER, Vicente Martínez.

COLOMER, Vicente Martínez. [1792] 1985. El Valdemaro, ed. Guillermo CARNERO, Alicante, Instituto de Estudios "Juan Gil-Albert".

CUETO, Leopoldo Augusto de, ed. 1869. "Bosquejo histórico-crítico de la poesía castellana en el siglo XVIII", en Poetas líricos del siglo XVIII, Madrid, Rivadeneyra (BAE, 61).

DÉROZIER, Albert. 1968. Manuel Josef Quintana et la naissance du libéralisme en Espagne, París, Les Belles Lettres.

DIDEROT, Denis. 1959. Oeuvres esthétiques, ed. Paul VERNIERE, París, Garnier.

ESCOIQUIZ, Juan de, trad. 1789-1797. Obras selectas de Eduardo Young, expurgada de todo error, y traducidas del inglés al castellano, Madrid, Imprenta Real.

ESTÈVE, Edmond. 1923. Etudes de littérature préromantique, París, Honoré Champion.

EZQUERRA DEL BAYO, Joaquín. 1929. El Palacete de la Moncloa. Su pasado y su presente, Madrid, Sociedad Española de Amigos del Arte.

- 1959. La duquesa de Alba y Goya, Madrid, Aguilar.

FOUCAULT, Michel. 1966. Les Mots et les choses, París, Gallimard.

FRIEDMAN, Winifred. 1976. Boydell's Shakespeare Gallery, New York-London, Garland.

GASSIER, Pierre y WILSON, Juliet. 1971. Goya. His Life and Work, with a Catalogue Raisonné of the paintings, drawings and engravings, Londres, Thames and Hudson.

GAY, Peter. 1967. The Enlightenment: an interpretation. The rise of modern paganism, Londres, Weidenfeld Nicolson.

GLENDINNING, Nigel. 1963. "Goya and Arriaza's Profecía del Pirineo", Journal of the Warburg and Courtauld Institutes, XXVI, pp. 363-366.

- 1992. Goya. La década de Los Caprichos. Retratos 1792-1804, Madrid, Real Academia de Bellas Artes de San Fernando.

— ed. 1993. Véase CADALSO, José.

GRAY, Thomas. 1903. The Works of Thomas Gray in Prose, ed. Edmund GOSSE, Londres, Macmillan.

GUÉRIN DE TENCIN, Claudine Alexandre. 1749. Mémoires du Comte de Comminge, París, Bibliothèque de Campagne.

KRAFFT, Johann Carl y RANSONNETTE, Nicolas. s.a. Plans, coupes, élévations des plus belles maisons et des hotels construits à Paris et dans les environs, Paris, Pougens. 
HAUSER, Arnold. 1951. Social History of Art, Londres, Routledge and Kegan Paul.

LOAISEL DE TRÉOGATE. 1785. Dolbreuse ou l'Homme du siècle, ramené à la vérité par le sentiment \& par la raison, París, Bélin.

McCARTHY, Michael. 1987. The Origins of the Gothic Revival, New Haven-Londres, Yale UP.

PEMÁN y MEDINA, María, ed. 1992. Véase Marqués de UREÑA.

PRAZ, Mario [1930] 1948. La carne, la morte e il diavolo nella letteratura romantica, Florencia, Sansoni.

QUINTANA, Manuel José. 1813. Poesías, Madrid, Imprenta Nacional.

- 1852. Obras completas, Madrid, Rivadeneyra (BAE, 19).

RANSONNETTE, Nicolas. Véase Johann Carl KRAFFT.

REEVE, Clara. 1967. The Old English Baron. A Gothic Story, ed. James TRAINER, Londres, Oxford UP.

ROSENBLUM, Robert. 1967. Transformations in Late Eighteenth Century Art, Princeton UP.

SANCHO, José Luis. 1989a. "Proyectos de Dugourc para decoraciones arquitectónicas en las Casitas de El Pardo y El Escorial (1)", Reales Sitios, XXVI, 101, pp. 1731.

- 1989b. "Proyectos de Dugourc para decoraciones arquitectónicas en las Casitas del El Pardo y El Escorial (2)", Reales Sitios, XXVI, 102, pp. 31-36.

SPURGEON, Caroline Frances Eleanor, ed. 1907. Véase Horace WALPOLE.

STERN, Jean. 1930. A l'Ombre de Sophie Arnould. François-Joseph Belanger, architecte, París, Plon.

STURM, Christoph Christian. 1803. Reflexiones sobre la naturaleza, o consideraciones de las obras de Dios en el orden natural: escritas en alemán para todos los días del año... traducidas al Francés, y de éste al español, Madrid, Benito García y Compañía.

TOSCA, Tomás Vicente. [1712] 1794. Tratados de arquitectura civil, montea y cantería, y relojes, Valencia, Hermanos de Orga.

TRAINER, James, ed. 1967. Véase Clara REEVE.

UREÑA, Marqués de. 1992. El viaje europeo del marqués de Ureña (1787-1788), ed. María Pemán Medina, Cádiz, Unicaja.

- 1785. Reflexiones sobre la arquitectura, ornato y música de los templos, Madrid, Joaquín Ibarra.

VERNIÈRE, Paul, ed. 1959. Véase Denis DIDEROT.

WALPOLE, Horace. [1764] 1907. The Castle of Otranto, ed. Caroline F.E. Spurgeon, Londres, Chatto and Windus.

YOUNG, Edward. Véase Juan ESCOIQUIZ y Pierre LE TOURNEUR. 